\title{
Boom-Time Freaks or Heroic Industrial Pioneers? Clothing Entrepreneurs in Sixteenth- and Early Seventeenth-Century Berkshire
}

\author{
Christine JACKson
}

The early emergence of the entrepreneur in the English cloth industry was commemorated by early modern writers such as Skelton, Leland, Deloney, Aubrey, Fuller and Defoe but remains neglected in recent studies exploring industrial expansion and innovation c. I500-I700. In response to the gap in the current historiography, this article examines the emergence of entrepreneurship, the growth of organizational experimentation and the short-lived development of the proto-factory in the Berkshire towns of Reading and Newbury. It explores the entrepreneurship of industrial capitalists such as John Winchcombe (the illustrious 'Jack of Newbury'), Thomas Dolman, Thomas Aldworth and William Kendrick and the nature of their achievement and motivation. It assesses the impact of market forces, locational advantages, product specialization and social attitudes in unleashing and shaping entrepreneurial investment from the expansion of cloth-making in the towns in the fifteenth century to de-industrialization in the seventeenth century.

\section{INTRODUCTION}

The golden age of England's broadcloth industry in the early sixteenth century saw the emergence of entrepreneurial clothiers of national fame. The industrial success and social advancement of men such as William Stumpe of Malmsbury, Thomas Spring of Lavenham, Thomas Horton of Bradford-on-Avon, Thomas Paycocke of Coggleshall, Peter Blundell of Tiverton and John Winchcombe of Newbury commanded the respect and envy of contemporaries and attracted celebration or satirical comment in literary works by Skelton, Leland, Deloney, Aubrey, Fuller, Defoe and others, from the sixteenth to the eighteenth centuries. ${ }^{\mathrm{I}}$ The reputation of John Winchcombe has undoubtedly proved the most enduring. Thomas Deloney's novel, The pleasant Historie of John Winchcomb, in his yonguer yeares called Jack of Newbery, The famous and worthy Clothier of England, was published in I597 and proved an instant bestseller, running through numerous editions from the seventeenth to the twentieth centuries. Several chapbooks followed and an opera written to celebrate the wedding of George, Prince of Wales and Caroline of Brunswick in $1795 .^{2}$ Throughout, John Winchcombe is cast as a self-made, working-class hero, rising from industrious weaver to gentleman clothier and providing a role model for other ambitious artisans. Taking Deloney's fictional Jack 


\section{Boom-Time Freaks or Heroic Industrial Pioneers?}

of Newbury as its starting point, this article explores the entrepreneurial success and motivation of leading Berkshire clothing families in the sixteenth and early seventeenth centuries. It examines the factors unleashing and shaping their entrepreneurship and challenges D. C. Coleman and A. R. Bridbury's dismissal of Winchcombe and Stumpe as 'boom-time freaks' and 'men intoxicated by a sort of folie de grandeur'. 3

\section{Investment, Innovation and Expansion in the Berkshire Cloth Industry}

Although the term 'entrepreneur' did not enter the English language until the eighteenth century, entrepreneurial skills and aspiration are evident in the English cloth industry by the early sixteenth century. ${ }^{4}$ Cloth-making spawned two types of entrepreneur mercantile capitalists and industrial capitalists - who invested time, money and effort in the expansion of cloth production based upon their knowledge of markets and manufacture and their perception of the risks incurred in the pursuit of profit. The term clothier was used to describe both. Whereas mercantile capitalists restricted their involvement in manufacture to the procurement and supply of materials and co-ordination of the putting-out system, industrial capitalists directly managed one or more of the major production processes in centralized workshops. Both provided fixed as well as circulating capital, but industrial capitalists invested in plant and buildings for manufacture as well as for storage. Both transformed a cloth industry previously dominated by the guild system, introducing not only the separation of capital and labour and a more effective division of labour, but also economies of scale, closer control of quality standards and new marketing practices. ${ }^{5}$ The range and impact of the changes varied from business to business according to the degree of direct control exercised over the production process.

The Berkshire cloth industry provides an ideal focus for a study of entrepreneurship because, unlike other clothing regions, the county spawned industrial rather than mercantile capitalists. By the early sixteenth century, production was concentrated in the Kennet valley region around the neighbouring towns of Reading and Newbury. Both towns enjoyed considerable locational advantages and benefited from the expanding demand for high quality cloth for the export market in the fifteenth and sixteenth centuries. ${ }^{6}$ These towns number amongst the few that survived the migration of woollen manufacture from town to countryside in the fourteenth century and prospered as industrial centres during the fifteenth and sixteenth centuries. Reading specialised largely, though not exclusively, in the manufacture of long coloured broadcloths, while Newbury was renowned for its coloured kersies. ${ }^{7}$ Although both towns utilized rural labour from a comparatively wide hinterland, the production of dyed and dressed cloths created a larger industrial sector in the Berkshire towns than found in most towns of similar size and function during the period. ${ }^{8}$ The pattern of economic growth in the two towns was also influenced by their individual political circumstances. Reading achieved borough status in $\mathrm{I} 253$ and was a major provincial centre. Its government and economy were dominated from the twelfth to the sixteenth centuries by Reading Abbey, and it was only in the aftermath of the dissolution of the monasteries under Henry VIII, a period of economic dislocation, that the mayor and burgesses of the town's merchant guild secured incorporation and control of municipal government. ${ }^{9}$ Newbury escaped 
close ecclesiastical supervision and remained under manorial administration and the government of leading members of the 'commonalty of the town' until formally incorporated as a borough in I596. ${ }^{\mathrm{IO}}$ Both towns afford prime examples of early innovation in industrial organization - especially Newbury, where entrepreneurial activity initially benefited from the relative absence of urban regulation.

The size and structure of the cloth-making businesses operated by industrial capitalists in the two towns varied considerably. Towards the lower end of the spectrum was the weaver-clothier or clothworker-clothier who sorted and carded wool on-site, ran a substantial weaving or cloth-finishing workshop and used outworkers or sub-contractors for the remaining manufacturing processes. At the top was the clothing entrepreneur who, with the probable exception of spinning, sought to centralize production in a proto-factory and leased or purchased a fulling mill. ${ }^{\text {II }}$ Businesses changed their position on the spectrum as they expanded and contracted in response to new opportunities and changing operating conditions. The towns' leading clothiers were typically responsible - either directly or through subordinates - for undertaking business planning; purchasing, leasing and maintaining plant and property; procuring materials; hiring, firing and supervising workers and sub-contractors; directing and overseeing on-site manufacturing; instituting quality standards and controls; marketing and merchandising cloth; and maintaining and auditing business accounts. They usually obtained wool direct from the farm or specialist wool markets and dyestuffs direct from importers or suppliers. They sold most of the cloths they produced in the London export market and created additional product demand by building up a brand reputation for quality and reliability. They enjoyed considerable influence in their local communities and were able to exert pressure upon both local and national government to protect or further their own economic interests.

\section{The Entrepreneurial Achievement of John Winchcombe of Newbury}

Deloney's selection of John Winchcombe to star in his first 'rags to riches' novel about artisan entrepreneurial success was no accident. Winchcombe enjoyed exceptional business success and towered above contemporaries in his reputation for quality and organizational innovation. Deloney's account is, however, only loosely and selectively based on items of historical record. He relied heavily on oral tradition, but as a commercial writer with a distinctly late sixteenth-century social agenda, he generated and plagiarized supplementary material to titillate his readership and to highlight inequities and inconsistencies endemic in the social hierarchy of the period. ${ }^{\mathrm{I} 2} \mathrm{He}$ presented his fictional Winchcombe as a thrifty and hardworking weaver, who expanded through his own entrepreneurial efforts the flourishing business pushed upon him by a sexually voracious clothier's widow. Deloney emphasized not only the scale of Winchcombe's enterprise and the extent of his political and economic influence, but his gentlemanly qualities and acceptance in country and court circles. Like other cloth-making families, the Winchcombes engaged in manufacture over several generations and Deloney never clarified whether his subject was John Winchcombe, the pioneer entrepreneur (died I5I9), or his son, also John Winchcombe (died I 557). Writers from Thomas Fuller in his Worthies of England (1662) to Eric Kerridge in the New Dictionary of National Biography (2004) 


\section{Boom-Time Freaks or Heroic Industrial Pioneers?}

have cast John Winchcombe I as Jack of Newbury, but comparison with other sources suggests a closer identification with his son or the creation of a composite character drawn from the lives of father and son. ${ }^{\mathrm{I} 3}$ Certainly the incidents Deloney recounted to demonstrate Winchcombe's successful interventions to resist shortcomings in Tudor economic policy appear to be based on political activities undertaken by John Winchcombe II and it is likely that the family cloth-making business expanded and achieved peak profitability under his management during the I530s and I540s.

Little is known of the wealth and business activities of John Winchcombe I. He numbered amongst the leading tradesmen of early sixteenth-century Newbury and was probably an economic migrant drawn to the town by the profitability of kersey-making in the late fifteenth century. His will of I520 reveals a clothier who leased lands and tenements from the College of Windsor and had accumulated sufficient funds to enjoy a comfortable life-style and leave generous bequests to family, friends and church. ${ }^{\mathrm{I}}$ Two years later, his son and heir, John Winchcombe II, was assessed as the richest man in Newbury in the muster return of I522. The valuation of $£ 6326 \mathrm{~s} 8 \mathrm{~d}$ placed upon his moveable possessions represented 24 per cent of Newbury's total assessment of $£_{2}, 65 \mathrm{I}$ I6s $8 d$. His nearest rival, the clothier, Robert Sewey, was assessed on a mere $£_{\mathrm{I}} 336 \mathrm{~s}$ $8 d .{ }^{15}$ Winchcombe paid almost a quarter of Newbury's total subsidy contribution in I523-27. ${ }^{\text {I6 }}$ Although Winchcombe occupied a dominant position within Newbury's urban economy, his wealth was dwarfed by that of other wealthy clothiers of the period. The moveable possessions of Thomas Spring III of Lavenham, Suffolk, were valued at $£_{\mathrm{I}}, 800$ in the muster of $\mathrm{I} 522$ and he owned 26 manors together with other houses and land, in four counties. His widow and daughter paid 37 per cent of the total subsidy of $£_{\mathrm{I} 79}$ I3s od raised in Lavenham in I524. Thomas Horton of Bradford-on-Avon, Wiltshire, contributed 70 per cent of the town's subsidy payment in $1523-27 .{ }^{17}$

Over the following 20 years John Winchcombe II acquired an enviable reputation for the scale and quality of his cloth-making and increased his personal fortune. Florence Edler's study of the Van der Molen correspondence for the years I538 to I544 reveals that the Antwerp commission house graded the kersies it purchased into three classes, assigning only Winchcombe kersies and those of two other producers to the highest grades, and paying consistently more for Winchcombe kersies than for other kersies. ${ }^{\mathrm{I}}$ The decision of Thomas Cromwell, Henry VIII's chief minister, to order I, ০০o Winchcombe kersies in 1539 in order to settle a debt in Antwerp, and the recommendation of William Dansell, the royal agent in the Netherlands, in I546 that, although there was 'wondrous little profit to be had presently in cloths or kersies[,] it shall be best to have hither [Antwerp] I, ০oo of Winchcombe kersies', are similarly indicative of Winchcombe's reputation, but may inadvertently overplay his manufacturing capacity. ${ }^{19}$ The demand for Winchcombe kersies at times clearly exceeded supply. During a frenzy of kersey buying in Antwerp in I538, English merchants rationed Winchcombe kersies to buyers willing to take an equal number of kersies from other clothiers. ${ }^{20}$ In February I539 Winchcombe advised Cromwell that time was short but he would 'make such shift ... to have readye fiv[e] hundrede $\mathrm{p}[\mathrm{ie}]$ ces against $\mathrm{E}[\mathrm{a}]$ ster' and it must be assumed that this was the best he could achieve in the time available. ${ }^{2 I}$ There was little scope to increase production significantly with a three to four week manufacturing cycle so he probably diverted kersies from other orders. In consequence, he struggled to supply the Van der 
Molens during the early summer of I 539 but it would have been impolitic not to pull out all the stops for the King's chief minister. ${ }^{22}$

More substantial evidence of Winchcombe's exceptional manufacturing output can be found in the account book of the young and upwardly mobile Merchant Adventurer, Thomas Gresham. During the period November I 546 to November I549, Gresham purchased nearly 4,000 kersies from Winchcombe. ${ }^{23}$ His orders ranged in size from 25 to 500 kersies, with the price increasing from $35 \mathrm{~s}$ to $43 \mathrm{~s}$ per cloth as English cloth exports soared due to deflation. Purchases were not spread uniformly throughout the year or from year to year. The pattern was determined in part by seasonal variations in output and by Gresham's shipping preferences, but the absence of purchases from November I547 to August I548 (a period when Gresham bought kersies from other Newbury clothiers) suggests that Winchcombe was selling to other buyers. Winchcombe's output was clearly substantial and a tentative estimate based solely on the evidence of the timing and scale of the Gresham purchases suggests that it exceeded 3,000 kersies per annum.

In his much-quoted verse account of Winchcombe's business operation, Deloney described a centralized proto-factory employing over I,ooo skilled, semi-skilled and unskilled workers. He listed Ioo carders, 200 spinners, 200 weavers and I 30 clothworkers, together with 250 children employed as pickers and quillers, working in large centralized workshops, and a further 60 men working in Winchcombe's dyehouse and fulling mill. The numbers are clearly rounded and exaggerated, but evidence form other sources confirms that clothiers employed large workforces during this period. ${ }^{24}$ William Stumpe, the Wiltshire clothier famed for establishing extensive weaving workshops on the site of Malmsbury Abbey, negotiated unsuccessfully with Oxford corporation in I546 to provide employment for 2,000 workers on the site of Osney Abbey. ${ }^{25}$ Robert Reyce wrote in I6I8 that a Suffolk clothier making '... 20 broadclothes every weeke cannot sett so few aworke as 500 persons ... ${ }^{26}$ An output of 3,000 kersies per annum would have required the use of some 60 narrow looms (each with a single weaver) if one kersey was woven per week throughout most of the year, or the use of some 40 looms if production levels averaged I.5 kersies per weaver per week. It is not feasible to estimate the size of the remaining workforce from the information available, but the number of skilled, semi-skilled and unskilled workers, employed both full- and part-time, was clearly considerable and could easily have exceeded 500.

Corroborating Deloney's assertion that Winchcombe centralized manufacture in a proto-factory also poses difficulties. The high volume and quality of his output, together with large purchases of wool from local flockmasters and dyestuffs from Southampton and London, provide circumstantial evidence to support Deloney's picture of a large proto-factory, but concrete evidence of extensive vertical and horizontal integration is fragmentary. ${ }^{27}$ Winchcombe's probate inventory of 1558 survives but is damaged and the indenture of his dyehouse, valued at $£_{4} \circ$, is the sole indication of his investment in cloth-making, albeit his flock of some 450 sheep valued at $£_{\text {IOO }} 6 s$ od is illustrative of his ambitious vertical integration. ${ }^{28}$ Unlike other clothiers of the period, he did not bequeath the lease or ownership of any fulling mills in his will, although he is reputed to have leased a fulling mill at Bagnor and enjoyed a close association with the lessees of West Mills near his business premises in Newbury. ${ }^{29}$ According to his father's will, 


\section{Boom-Time Freaks or Heroic Industrial Pioneers?}

he inherited a tenter ground, with equipment for drying and stretching his cloth after fulling. ${ }^{30}$

Both documentary and archaeological evidence confirms that Winchcombe's house, workshops and warehouses in Newbury occupied a substantial site. An inventory of the house taken in 1562 records the presence of workrooms for picking, sorting, carding and weighing wool, and storage lofts for wool and dyestuffs, but not accommodation for spinners, weavers or cloth finishers. ${ }^{3 \mathrm{I}}$ This does not necessarily preclude the presence and operation of manufacturing workshops on the site in the I530s and I540s when the rising demand for cloth coincided with rapid urban population growth and large carding, spinning and weaving workshops were seen as a means of providing employment for the poor. Amyce's survey of I554 indicates that Winchcombe owned other property in Newbury, any of which might have provided additional workshop accommodation. ${ }^{32}$ Winchcombe's reputation for the scale and quality of his output also suggests that he exercised tight control over the manufacturing process. It seems likely that he developed a composite business structure utilizing both putting-out and centralized workshop systems, thereby enabling him to expand and contract his operation flexibly in response to market conditions. Although the case is far from watertight, there appear to be reasonable grounds for accepting Deloney's literary assertion that Winchcombe's investment in centralization and conglomeration was exceptional before mid-century. Oral tradition, however, continues to provide the main basis for claims that he pioneered the development of the proto-factory.

Deloney's social and political agenda precluded coverage of Winchcombe's landowning or dynastic ambitions in Jack of Newbury, but both add lustre to a study of the clothier's wider entrepreneurial success. The Newbury clothier was an early beneficiary of the post-dissolution land bonanza. In I540 he bought the manors of Bucklebury and Thatcham with other property from the crown for the sum of $£_{2,6}$ I9 I $3 s 4 d .{ }^{33}$ In I 542 he acquired the lease of Farnborough Manor and in I547 that of Bartholomew's Farm in Newbury; in $\mathrm{I}_{548}$ he bought further Berkshire lands for the sum of $£_{\mathrm{I}, 068 .{ }^{34}}$ In an inquisition post mortem, taken in $155^{8}$, the annual value of his lands was assessed as $£_{\mathrm{I} 58}$, less than half that of Thomas Spring III's assessment in I523, but he had already in 1555 settled the manors of Bucklebury and Thatcham on his eldest son, John Winchcombe III. ${ }^{35}$ His probate inventory valued his personal estate at $£_{\mathrm{I}}, 878 \mathrm{I} 4 \mathrm{~s}$ od, the highest figure recorded for Newbury during the sixteenth century. ${ }^{36}$

Whilst Winchcombe's eldest son moved into the ranks of the gentry and the younger became a minor landowner, his middle son, Henry, married the daughter of Thomas Horton, the wealthy Wiltshire clothier, and took over the family clothing business. ${ }^{37}$ Henry Winchcombe was active as a clothier in the I540s, selling 600 kersies to Thomas Gresham between September I548 and March I 549. ${ }^{8}$ His business career was cut short by his early death in I562. This fact, coupled with the vicissitudes of the cloth trade in the I550s and Newbury's demographic difficulties $c$. I545-58, resulting from poor harvests, plague and influenza, makes it difficult to assess his entrepreneurial skills. ${ }^{39}$ The Winchcombe business appears to have been downsized during the I550s, since his probate inventory records a mere $30 \mathrm{kersies,}$ valued at $£_{30}$, in his wool loft, together with 40 tods of dyed wool and eight tods of white wool valued at $£_{45} 6 \mathrm{~s} 8 \mathrm{d.4^{ \circ }}$ The total valuation of $£_{254} 8 s$ Id placed upon his personal estate was significantly 
lower than that of his father. ${ }^{4 \mathrm{I}}$ At least one of his sons, Thomas, trained and worked as a clothier. ${ }^{42}$

\section{Other Successful Industrial Capitalists in Newbury and Reading}

Although D. C. Coleman and A. R. Bridbury downplay the entrepreneurial achievement of early industrial capitalists, stressing the exceptional trading conditions of the I530s and I540s and arguing that the technological condition of the cloth industry in the early modern period did not justify investment in centralization, John Winchcombe II was not, as sometimes suggested, devoid of imitators. ${ }^{43}$ By the late I540s, Thomas Dolman I (died I 575), son of William Dolman, a former employee of John Winchcombe I, was also producing high quality kersies on a large scale. During the period March I 548 to July I550 he sold nearly 4,000 kersies to Thomas Gresham at prices rising from $39 s$ to $43 s 6 d$ per kersey and with orders ranging in size from two to 800 kersies. ${ }^{44}$ Evidence of his substantial fixed capital investment in centralization can be gleaned from his will of I57I in which he bequeathed to his middle son, also Thomas, a dyehouse containing six woad vats, two float vats, two furnaces and other implements, together with both of his fulling mills at Greenham, with the houses and implements 'thereto belonging'. He also owned a mill at Colthropp. ${ }^{45}$ Like Winchcombe, Dolman's entrepreneurial success enabled him to accumulate a considerable fortune and to invest in land and sheep-farming. In the subsidy of $\mathrm{I}_{543}-45$ he was assessed at $f_{\mathrm{I}} 5 \mathrm{~s}$ on his lands and already ranked amongst the highest taxpayers in Newbury. ${ }^{6}$ He purchased the manors of Shaw in I554, and Colthrop in I555, with further land and mills in I557, for $£_{92} 3$ I $3 s 4 d$. In 1558 he bought Frethorne Manor, Childrey and the manors of Staunton and Snowshill in Gloucestershire, and in 1568 , with his son, Thomas, the manor of Speen in Berkshire. ${ }^{47}$ In his will, he left large cash sums to his wife $\left(£_{I}, \infty \circ\right)$, and sons John $\left(£_{700}\right)$ and Mathias $\left(f_{\mathrm{I}, \infty}, \mathrm{O}\right)$. Whilst his second son, also Thomas, trained and worked as a clothier until $c$. I580, his eldest son pursued a career in the law and his younger son became a leading London haberdasher..$^{48}$

Examination of muster and subsidy assessments suggests that other early sixteenthcentury clothiers in Newbury operated on a smaller scale than the Winchcombes and Dolmans, but their manufacturing capacity and investment in centralization were probably still significant by contemporary standards. ${ }^{49}$ For example, William Bennet, scion of a prosperous cloth-making family who rented fulling and tanning mills in Newbury as early as I436, supplied I,647 kersies to Thomas Gresham between August I548 to May 1550 , with a largest single order of 300 kersies. ${ }^{50}$ There is also tentative evidence of continuing investment and large-scale production in the Newbury cloth industry in the late sixteenth and early seventeenth centuries despite the impact of mid-century trading difficulties, the long-term decline in demand for fine kersies and increased government regulation of organizational size and product quality. The clothier, Brian Chamberlain (died I593), worked for Thomas Dolman I in the I540s and I550s but had clearly established his own substantial cloth-making business by the 1560 , because he fell bankrupt for $£ 6,000$ before I57I. ${ }^{51}$ He owned a house, workshops and land in Newbury and leased other land and property from the College of Windsor, including, from I 586, the three corn mills and one fulling mill known as Newbury Mills. ${ }^{22}$ The generous bequests of money, land and property left to family, friends, workers and the 


\section{Boom-Time Freaks or Heroic Industrial Pioneers?}

poor in Philip Kistill's will of I 592 suggest that John Winchcombe II's former employee also enjoyed considerable success and prosperity as a clothier. ${ }^{53}$ The will of one of Kistill's own former employees, Roger Weston, dated I620, records his probate inventory valuation of $£_{4}, 3238 \mathrm{~s}$ od but provides no details of his clearly sizeable clothmaking operation apart from his investment in fulling mills in Newbury. ${ }^{54}$ It is likely that by the late sixteenth century all three specialized in coloured broadcloth rather than kersey manufacture. As with most wealthy clothiers of the period, the poor survival rate of probate inventories filed in the Prerogative Court of Canterbury precludes more detailed study. The rise in the number of smaller clothiers in the early seventeenth century, using the putting-out system preferred by both central and local government agencies, is better documented. The probate inventory of the former Newbury mayor, William Camber, taken in I62I, provides a good example. It shows that wool was sorted, cleaned and carded in his lofts and outhouses but dyed by one of the town's dyers, and distributed to spinners in and around Newbury. His cloth was woven and probably dressed in independent craft workshops but burled in his own burling house. At the time of his death he had wool at the dyehouse, one broad cloth 'a spynninge', seven broadcloths and other yarn amongst the weavers, two broadcloths at the fulling mill, one remnant of cloth with a cloth-worker, seven broadcloths and a remnant in the shop, and one further cloth in London. His personal estate was valued at $£_{3}$ I 7 IOs $2 d .55$

Clothiers in Reading appear to have invested in centralized manufacture slightly later than their Newbury neighbours. Working practices laid down in 1520 to resolve disagreements between the town's clothiers and craftsmen indicate that the putting-out system was widely used in the early sixteenth century. Mercantile capitalists, such as the drapers Richard Cleche and William Wattes, seem to have provided the initial entrepreneurial drive for organizational innovation and expansion. However, by midcentury, most had been replaced by industrial capitalists, as ambitious clothing entrepreneurs emerged from the ranks of the weavers and cloth finishers to dominate both manufacture and urban government. ${ }^{56}$ Foremost amongst them was Thomas Aldworth, a migrant from Wantage. Evidence from his will, dated I576, and from Reading's Guild Rules, c. I570, reveals that his working premises included a dye-house with furnace, vats and cisterns and a weaving workshop with four broad looms and that he held an interest' in a fulling mill and burling workshop in Caversham. By Reading standards his investment in both vertical and horizontal integration were exceptional since by this date both government legislation and borough ordinances imposed tight restrictions upon the size and organization of cloth-making businesses. Thomas Aldworth blatantly used aldermanic seniority to secure exemption from guild rules restricting clothiers to the operation of two looms and prohibiting the finishing of cloth outside the borough. ${ }^{57}$ His business success is demonstrated by the large property portfolio listed in his will, including I I houses or tenements in Reading (nine freehold, one copyhold and one leasehold), together with a house in London, Wantage, and Tilehurst and land near Reading and Maidenhead. His eldest son, Thomas, pursued a career in London. At least two of his sons (Simon and Henry) trained and worked as clothiers, as did his brother, Richard Aldworth, and at least two nephews. ${ }^{58}$

The fortuitous survival of the probate inventory of Walter Bye, taken in 1580 , provides a detailed snapshot of the scale and profitability of cloth-making businesses run 
by the next generation of Reading clothiers, who were increasingly drawn from the cloth-finishing rather than the weaving trade. It lists a weighing house with table, beam, scales and weights; a stockarding house with six stockarding frames and eight pairs of stockards; a dye-house with a copper furnace and two vats; a warehouse containing dye-stuffs and oil and a workshop containing 2I pairs of shears and 27 courses of handles. ${ }^{59}$ His stock included over 60 broadcloths and I20 kersies, under manufacture or ready for sale. These, together with supplies of wool and yarn, were valued at $£_{\mathrm{I}, 453}$. His tools and equipment were valued at $£_{5} 66 \mathrm{~s}$ od and dyestuffs and oil at $£_{\mathrm{I}} 66$. The high value of Bye's trade goods indicates a significant level of investment in both fixed and circulating assets, albeit he used outworkers for spinning and weaving and, at this relatively early point in his career, owned no interest in a fulling mill. The gross valuation of Bye's inventory was $£_{2, \mathrm{I} 25} \mathrm{I} 8 \mathrm{~s} 2 \mathrm{~d}$, of which he left $£_{\mathrm{I}, 500}$ to his wife and young children. ${ }^{60} \mathrm{He}$ was a member of a long-established and well-connected Reading clothing family. ${ }^{6}$ His brother, Thomas, pursued a career in London in the prestigious Drapers' Company. ${ }^{62}$ His eldest son, also Walter, trained as a clothier. ${ }^{63}$

The more buoyant trading conditions and relaxed regulatory climate of the early years of the seventeenth century seem to have facilitated more extensive investment in centralization in Reading. The best documented example is provided by William Kendrick, who in 1626 sold a house, workshops and warehouses, inherited from his father, the clothier, Thomas Kendrick, to the mayor and burgesses of Reading for $£_{I, 900 .}{ }^{64}$ He had clearly run a substantial proto-factory on the site previously. An inventory for the sale of '. .. such goods as ... does belonge to the trade of clothinge...' lists a dye-house containing three furnaces, a flat vat, two woad vats, a racking hurdle and frame; a meddling loft with beating hurdles; a stockarding house with eight pairs of stockarding frames and two handles; several weavers' shops containing six broad looms and two kersey looms and a cloth-workers' house with 46 pairs of shears, II4 courses of handles, seven shear-boards, five racks and two presses. The equipment and tools were valued at $£_{\mathrm{I} 22 .}$. $^{5}$ There were also picking and weighing lofts and warehouses on site. Archidiaconal court and assize records reveal that his cloths were fulled at Burghfield Mills, which he owned or leased in partnership with Robert (and later, James) Winch. ${ }^{66}$ Kendrick presumably employed outworkers from Reading and the surrounding villages to spin. The presence of only six broad and two narrow looms in Kendrick's workshop is surprising because it suggests that he produced about eight cloths a week (about 400 cloths per annum) whereas the scale of his cloth-working operation suggests that some 24 cloths a week (nearly 25 per cent of the town's weekly output in the early I620s) were rowed, shorn and pressed on the premises. ${ }^{67}$ It seems likely that he owned or leased one or more weaving workshops in the town, although he may also have subcontracted part of his weaving operation. ${ }^{68}$

William Kendrick numbers amongst seven Reading clothiers praised by the Company of Merchant Adventurers who '... make trewe cloth ... [and] n[e]ver faile of speedie vent of all their cloth ...'. According to wholesale prices quoted by the Company c. I630, an output of 400 cloths would have produced a gross income of $£_{4}, 000-£_{4}, 800$ per annum, whilst an output of I,200 cloths would have netted $£_{\text {I } 2,000} £_{\text {I } 4,400}{ }^{69}$ He was certainly well placed in the I60os to marry a local gentlewoman and in the I620s to purchase the manor of Whitley Park, near Reading. ${ }^{70}$ His son, Thomas, trained and worked as a clothier but struggled in the difficult trading conditions of the I6zos 


\section{Boom-Time Freaks or Heroic Industrial Pioneers?}

and I640s. ${ }^{7 \mathrm{I}}$ His elder brother, John, attended Oxford University but later trained as a draper in London, where he developed a highly profitable trade as a Merchant Adventurer, exporting dyed and dressed broadcloths and kersies. ${ }^{72}$

\section{The Emergence of Industrial Capitalists in Berkshire}

Why did entrepreneurs willing to make significant capital investments in fixed as well as circulating assets emerge at an early date in the Berkshire cloth industry? Market forces were obviously a major factor. The expanding and highly profitable market for woollen broadcloths and kersies in Europe between about I460 and I550 provided ideal conditions for the development and exploitation of entrepreneurial skills. English clothiers, with abundant supplies of home-produced fine wool, were better placed to meet the increase in demand than their Netherlander and Italian competitors who were dependent upon highly-taxed imported wool and temporarily weakened by military conflict. ${ }^{73}$ The fact that the rising level of inflation in England lagged behind those of other European countries provided a price advantage and low export duties also operated in their favour. English cloth exports increased more than three-fold with significant spurts of growth from the I470s to the early I480s, around I500 and particularly from the I 530 s to the early I550s. ${ }^{74}$ Despite intermittent dislocations of trade, the demand for high quality broadcloths and kersies frequently exceeded supply, with sales at Antwerp between about 1520 and I 550 netting a trading profit of about 20 per cent. ${ }^{75}$ Newbury kersies competed successfully with Netherlander, Italian and French woollens in the Mediterranean, Levant and Central and Eastern Europe throughout the first half of the sixteenth century but thereafter the market for fine kersies (as opposed to cheaper Yorkshire kersies) failed to recover from the trade crises of the I550s, the decline of Antwerp from $\mathrm{I}_{5} 63$, the prolonged power struggle between the Venetians and Ottomans in the Mediterranean basin and the growing demand for new drapery products. ${ }^{76}$ Clothiers in Reading benefited both from the general buoyancy of demand in the early sixteenth century and the popularity of their long medley cloths in northern and central Europe in the late sixteenth century but by the I620s were increasingly out-priced by producers of traditional woollens and new draperies at home and abroad. ${ }^{7}$

Locational advantages also played a key role. Berkshire entrepreneurs were geographically well placed to expand production and pioneer organizational innovation in Newbury and Reading. High-quality wool was available from the Berkshire and Hampshire Downs. ${ }^{7}$ Oil and imported dyestuffs were procured in London and Southampton; woad, fuller's earth and firewood were purchased locally. ${ }^{79}$ The multi-channelled river Kennet and its tributaries provided water power in and around the towns. ${ }^{80}$ The growth of cloth-making in the towns during the fifteenth century had established a substantial skilled workforce and enclosure, migration and rising birth rates supplied further labour for continuing expansion at levels sustainable by local agriculture. Ross Wordie points out that villages in West Berkshire experienced some of the highest enclosure levels in the county during the period 1485 to $1550 .^{81}$ Newbury's population appears to have expanded rapidly from the late fifteenth century, possibly reaching 2,700 by the $1520 .^{82}$ The renewed expansion of cloth-making in late sixteenth-century Reading was doubtless facilitated by the rapid population growth and increased migration of the period. The 
town's population is estimated to have more than doubled from the I550s to the I6IOS and to have peaked at over 6,000 by $1630 .^{83}$

Berkshire's specialization in dyed and dressed rather than semi-manufactured cloths encouraged industrial rather mercantile capital investment because, even before the introduction of power-driven spinning and weaving machines, centralization offered significant organizational and manufacturing benefits to high-volume producers of fullymanufactured woollens. It enabled clothiers to achieve greater control over both production cycle and workers, improve co-ordination of the major production processes and increase productivity and throughput, thereby increasing the velocity of circulating capital and generating higher profits. Providing on-site accommodation for members of the workforce encouraged a more effective division of labour, facilitated the training of workers, allowed close observation and supervision of working technique and practice, and rendered fraudulent workmanship and the embezzlement of raw materials more difficult. ${ }^{84}$ It may also have improved labour discipline and commitment, particularly attendance and timekeeping, during a period when low consumption levels among workers encouraged a preference for leisure rather than increased income. ${ }^{85} \mathrm{Wage}$ costs may have been reduced depending upon the ratio of master craftsmen, journeymen and apprentices employed. Most importantly of all, however, centralization afforded significant quality gains through close attention to the quality of raw materials purchased, to the fastness and shades of dyes used, to the consistency and strength of yarn spun, to the accuracy of weaving, to the care taken during the fulling and tentering processes, and to the finish achieved during cloth-finishing. Even the partial centralization favoured by many Berkshire clothiers brought most of these benefits. Unfavourable comparisons made by historians with the contemporary putting-out system underestimate the fixed capital investment needed for high-volume domestic production and do not take into account the high level of circulating capital required under both systems. The level of circulating capital frequently equalled or exceeded that of fixed capital investment, and when trade was dislocated or uncertain, posed a greater financial risk. ${ }^{86}$

The pool of potential entrepreneurs was inevitably limited by access to adequate financial resources and the possession of the requisite personal attributes. The pioneering industrial entrepreneurs of Newbury and Reading were frequently former master weavers or cloth-finishers, although a few, like Thomas Kendrick, were drawn from the distributive trades. ${ }^{87}$ Start-up capital for their businesses was obtained from father or employer as gifts, loans or legacies, through marriage to a young clothing heiress or wealthy clothier's widow or from loan funds established by charitable benefactors. Deloney's assertion that Jack of Newbury acquired his clothing business through marriage to a 'very comely ancient' clothier's widow cannot be proven but may explain the economic ascent of John Winchcombe I or the exceptional wealth of John Winchcombe II in the I520s. ${ }^{88}$ Thomas Aldworth certainly inherited a weaving workshop and dye-house from his wife's father, John Barfoot whilst Roger Weston was bequeathed $£_{20}$ or the lease of two houses by his employer, Philip Kistill. ${ }^{89}$ Michael Zell calculates, from a study of Wealden probate inventories in the late sixteenth century, that a modest mercantile capitalist needed start-up capital of about $£_{\text {IOO }}$. He estimates that $£_{\text {IO }}$ was needed to erect a workhouse, $£_{25}$ to buy equipment, $£_{25}-£_{5}$ o to buy stocks and a further $£_{\text {IO }} £_{\text {I } 5}$ to cover wages laid out before payment was received for cloth. ${ }^{90}$ Evidence from 


\section{Boom-Time Freaks or Heroic Industrial Pioneers?}

Reading and Newbury suggests that merely equipping a small proto-factory with dyeing, weaving and cloth-finishing equipment in the early seventeenth century cost in the range of $£_{\mathrm{I} 20}$ to $£_{\mathrm{I} 90}$, depending on whether items were purchased new or secondhand.9 ${ }^{9}$

In most cases, start-up costs were undoubtedly spread over a period of years through gradual vertical and horizontal integration. The earliest industrial capitalists in both Newbury and Reading appear to have been weavers who increased the number of looms in their shops and invested in a dye-house. As production and profit levels soared, successful industrial capitalists sought direct supervision of the cloth-finishing processes, and, when profits and availability permitted, invested in a fulling mill. The money for expansion was obtained through ploughing profits back into the business and exploiting credit relationships by purchasing raw materials and labour on credit and requiring rapid payment for cloths produced. Although there was some potential for maximizing profits by buying and selling when market conditions were favourable and negotiating higher profit margins through offering rather than accepting credit to secure raw materials and sales, much depended on demand. Leading clothiers seem to have preferred the certainty and convenience of regular commercial relationships, even during the elastic trading conditions of the I540s. As valued quantity and quality suppliers to Thomas Gresham, John Winchcombe II and Thomas Dolman I were paid a higher rate for their cloths, received substantial cash part-payments on delivery and probably purchased dyestuffs at discounted prices. ${ }^{92}$

\section{The Entrepreneurial Motivation of Berkshire Clothiers}

Deloney fully appreciated the exceptional qualities needed by successful entrepreneurs in the early modern cloth industry and emphasized John Winchcombe II's drive, opportunism and work ethic. Winchcombe also clearly possessed the commercial judgement needed to evaluate business risks in uncertain operating conditions. Mark Casson singles out such judgement as the key attribute of the successful entrepreneur, over and above organizational, inter-personal and self-promotional skills and personal ambition. ${ }^{93}$ Deloney appeared less dependable in his presentation of entrepreneurial motivation. In stressing Winchcombe's chivalry, hospitality and charity, he unrealistically downplayed the motivational role of personal egotism and cupidity in favour of patriotism and paternalism. A rather different picture emerges from a study of the known activities, expenditure and achievements of leading Berkshire clothiers and from the provisions made and sentiments expressed in their wills. These suggest that the attainment of financial security and the enjoyment of a comfortable life-style were significant initial goals, but that once a modest degree of success had been achieved, other factors kicked in, including the desire to emulate the trading and social success of relations and competitors, the ambition to exercise political power and influence, the aspiration to secure social advancement, and for some, the enjoyment of exceptional occupational success per se.

Probate sources provide clear evidence of the universal desire amongst the clothiers studied to safeguard their financial position, live in comfort and style and make generous provision for their children. Although cloth-making raked in high profits when the demand for broadcloths and kersies was buoyant, the cloth export trade was extremely volatile and easily disrupted by war, changes in exchange or customs rates, commercial 
dispute and infectious disease. All of the clothiers studied diverted a significant proportion of their surplus profits to secure low-risk investments such as plate, land and property. Probate evidence suggests that the Winchcombes and Dolmans invested fairly heavily in plate, individual items of which were passed on as family heirlooms. John Winchcombe I, for example, divided his plate and moveable possessions between his wife and son; Thomas Dolman I willed the custody of his plate to his wife 'as longe as she keepth herselfe widowe' and to his eldest son if she remarried or when she died, but also bequeathed individual items to his two younger sons. ${ }^{94}$ Land provided an even more secure investment because it was less vulnerable to punitive rates of taxation. John Winchcombe II purchased manors in West Berkshire in the I540s and Thomas Dolman I in West Berkshire and Gloucestershire in the $15505 .{ }^{95}$ In the following decades, Thomas Aldworth and Thomas Kendrick invested more modestly in land in and around Reading. ${ }^{96}$ All took a market view of land and most engaged directly in agriculture, especially, in the case of Winchcombe and Dolman who took up sheep farming. ${ }^{97}$ Investment in urban property offered both a rising rental income and appreciating capital value. Joan Dils's study of properties rented from the churchwardens of St Mary's Church, Reading suggests that rents rose five- or six-fold during the second half of the sixteenth century..$^{98}$ Thomas Aldworth invested much of the wealth he accumulated from cloth-making in property released by the successive dissolutions of Reading's abbey and religious guilds. ${ }^{9}$

In a period when social status and reputation depended heavily upon conspicuous consumption and generous hospitality, it is not surprising that wealthy clothiers emulated the living standards and life-styles of the gentry (Fig. I). Deloney's glowing account of the scale and quality of John Winchcombe II's house and hospitality is confirmed by documentary and architectural evidence. The reception, sleeping and service accommodation of his house in Northbrook Street where he had I8 rooms, was laid out around two courtyards with a gatehouse from the street and an inner gatehouse to the second

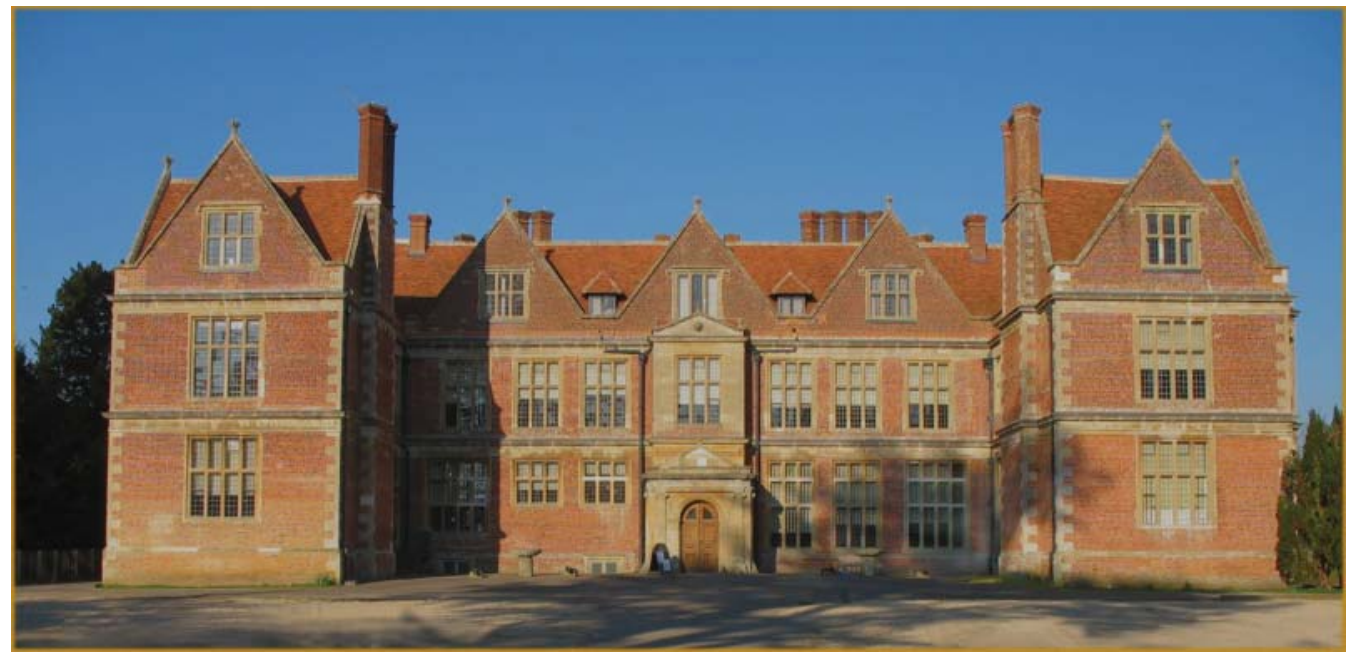

FIG. I. Shaw House, near Newbury, Berkshire, 2008. Photo: Roy Jackson. 


\section{Boom-Time Freaks or Heroic Industrial Pioneers?}

courtyard. ${ }^{100}$ An eighteenth-century sketch shows an imposing two-storey timber framed building with projecting gables, decorated barge-boards and arched doorways. ${ }^{\text {Ior }}$ Nineteenth-century surveys of the site confirm Deloney's assertion that the hall and other reception rooms were wood-panelled and reveal the extensive use of expensive carved decoration. ${ }^{102}$ Winchcombe's will provides insights into his luxurious life-style from his down feather bed and high quality linen to gilt tableware. ${ }^{\mathrm{IO} 3}$ Details of the spacious and richly furnished house occupied by Thomas Aldworth can be gleaned from his widow's probate inventory which lists ro rooms plus ancillary service buildings. With her pictures and painted cloths, fine bedcovers and damask tablecloths, gilt goblets and silver spoons, Alice Aldworth was clearly a widow of substance. ${ }^{104}$

Several clothiers followed the example of the aristocracy and gentry in carving out a substantial landed inheritance for their eldest surviving son, but they also made provision for younger sons and daughters. John Winchcombe II settled his prime manors of Bucklebury and Thatcham upon his eldest son and smaller estates upon his younger sons, giving them all a 'gentlemanly start in life'. His daughter received a cash dowry. ${ }^{\text {105 }}$ Thomas Kendrick left his property at Burghfield to his elder son, and his Reading house to his younger son with further property bequests to his daughters. ${ }^{\text {Io6 }}$ Thomas Dolman settled a manor apiece upon his eldest and youngest sons, together with a substantial cash sum, but controversially left most of his Berkshire manors and his property in Newbury to his middle son, Thomas. His daughter received a cash dowry. The will was overturned during the inquisition post mortem and Thomas Dolman II only secured possession of the manors of Shaw, Colthrop and Speen by buying out his elder brother. ${ }^{107}$ Uniquely, Thomas Aldworth appears to have divided his property equally between his four sons and made generous provision (two houses or tenements apiece) for his two married daughters. ${ }^{108}$ The apparent rejection of preferential partibility and primogeniture may indicate a Puritan suspicion of hereditary privilege and careful stewardship of wealth considered a sign of God's approval and favour.

The extent to which Berkshire clothing families actively sought gentle status and absorption into the local parish or county gentry, or were motivated to pursue and exploit entrepreneurial opportunities by the prospect of glittering social rewards, is open to debate. ${ }^{109}$ Michael Mascuch is right to question universal assumptions about the social aspirations of the 'middling sorts' but individuals of exceptional talent and ambition appear to present a special case. ${ }^{\text {IIo }}$ Social attitudes clearly had an impact upon the development and duration of early modern entrepreneurship in a status-conscious society where theologians and philosophers condemned covetousness and despised labour. ${ }^{\text {III }}$ The need to conquer unemployment and the rise of the Protestant work ethic produced only gradual and often temporary changes in such attitudes. ${ }^{\mathrm{II} 2}$ Although social mobility increased during the sixteenth century, society remained a hierarchical structure dominated at its highest levels by the possession of land, lineage and education. Gentle status and its associated privileges were highly coveted. Martin Weiner's thesis, that the dominant culture in England is anti-industrial because it expresses aristocratic values emanating from a rural way of life, although developed to explain the failure of entrepreneurship in the nineteenth century, has some relevance here. ${ }^{113}$ Whilst wealthy clothiers were fêted for their business success in the early decades of the sixteenth century, attitudes towards social rank remained conservative, and the economic power 
they wielded, even when weighed alongside their political and social contribution to the common weal, was only in exceptional cases sufficient to gain them entry to county society and politics. It did not secure them a clearly designated place in the social hierarchy. Although the governing classes were initially willing to accept, and exploit for their own purposes, the social aspirations of wealthy clothiers within their counties, from mid-century onwards, there are indications that they had grown concerned about the local power of rich industrialists and were actively seeking to resist their advancement. ${ }^{\text {II }}$ The change in attitude followed both the social disorders of I 549 and the rising tide of disinvestment provoked by the prolonged and severe trading difficulties of the I550s and early I560s, but also reflected the ruling elite's growing concerns about the over-dilution of gentility.

Unusually, John Winchcombe's exceptional entrepreneurial success appears to have smoothed the way for him to be accepted as a gentleman and to mix with county society and members of the royal court even before he purchased land and acquired arms. The chronology of his social advancement is instructive. In I537, he extended hospitality to Edward Seymour, Earl of Hertford (uncle to the future Edward VI) and his retinue. II In I540, he numbered, perhaps at Cromwell's instigation, amongst the esquires appointed to receive Anne of Cleves on her arrival in England. ${ }^{\text {I }}{ }^{6}$ His purchase of the manors of Bucklebury and Thatcham in the same year provided him with a country house and estate and enabled him to consolidate his claim to status and to a share in the political administration and judicial government of county and country. He was listed to supply men for military service in I536, I 543 and I 544 and granted a coat of arms in ${ }^{1549 .}{ }^{\mathrm{II} 7}$ In $\mathrm{I} 550$ he had his portrait painted. The portraitist is unknown but the large and skilfully painted panel shows Winchcombe as a gentleman, dressed in a black satin doublet and fur-lined surcoat, and holding gloves and a carnation, but with his clothier's mark displayed on the wall behind him (Fig. 2). ${ }^{\text {I8 }}$ By this date, he had accumulated surplus funds to build a new country house as a visible symbol of his family's arrival amongst the gentry. Both house and estate were transferred to his eldest son in $1555 .{ }^{119}$ It is not clear when - or whether - Winchcombe withdrew from active involvement in cloth-making, but it seems likely that he reduced the time committed to his business as his public duties and landowning responsibilities increased. He is the only clothier amongst those studied to describe himself as esquire in his will and to have achieved some degree of social acceptance amongst the county elite.

The Dolman family's social advancement bears the hallmark of careful planning. Between I554 and I568, Thomas Dolman I acquired a clutch of manors in Berkshire and Gloucestershire and built a house in Staunton between I 557 and I558. ${ }^{\mathrm{I} 20} \mathrm{He}$ remained a working clothier but dispatched his eldest son to university and the Inns of Court and his youngest to a prestigious London livery company. Both acquired gentle status. Thomas Dolman II, heir to the family clothing business, built a fashionable house of exceptional quality at Shaw between about I578 and I58I and thereafter abandoned cloth-making. ${ }^{\text {I2I }} \mathrm{He}$ was granted arms in ${ }^{5} 587$ and served as sheriff of Berkshire in I $588 .{ }^{122} \mathrm{He}$ married a gentlewoman and fathered two sons who attended university and pursued careers in the law and army. ${ }^{\mathrm{I} 23} \mathrm{His}$ response to criticism of his social ambitions and architectural extravagance was bitter and flamboyant: 'The toothless man envies the teeth of those who eat and the moles despise the eyes of the goats' was carved in Latin 


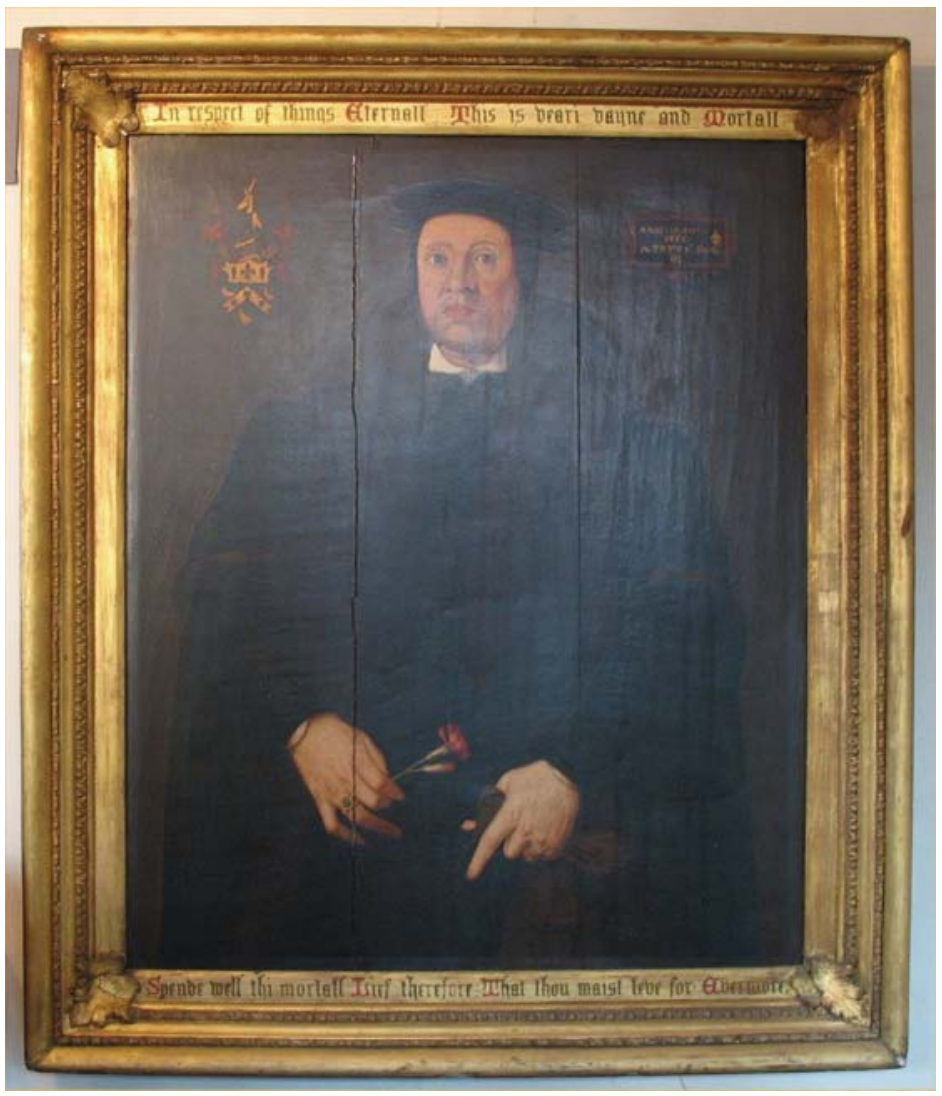

FIG. 2. Portrait of John Winchcombe, I550, artist unknown, oil on panel, $44 \times 36$ inches, West Berkshire Museum, NEBYM:I983.L8I. By kind permission of the West Berkshire Museum.

on a frieze above the front porch of his gentrified house and 'Let no envious man enter' inscribed in Greek on the porch itself. ${ }^{\mathrm{I} 24}$

In contrast, the Aldworths, Byes and Kendricks opted for civic rather than county gentle status, at least in the short term. The difference in aspiration appears to reflect social rather than geopolitical factors since several Reading mercantile entrepreneurs, including the mercer, Robert Blagrave, entered the ranks of the gentry in the early sixteenth century. ${ }^{\mathrm{I} 25}$ By the late sixteenth century, whilst an expanded landed elite was striving to consolidate its position and to protect its exclusivity, the growth of towns and burgeoning of civic independence and pride had created alternative opportunities for social advancement and it was possible to claim a coat of arms and the title of esquire or gentleman merely on the basis of income or office-holding. A new urbanized or 'pseudo' gentry emerged, which adopted the values and life-style of the landed elite - in areas as diverse as the size of their house, approach to hospitality and education and the commissioning of portraits and funerary monuments. They combined such activities with business and civic responsibilities. ${ }^{\mathrm{I} 26} \mathrm{It}$ is noticeable that whilst members of both the Aldworth and Kendrick families invested in rural property and agriculture, they did so on a fairly modest scale and remained based in Reading. Some of their sons worked as clothiers but others became minor landowners, entered London Livery 
Companies or pursued a career in the Church. Ultimately, however, members of both families were absorbed into the gentry.

Public service followed close in the wake of economic success and social advancement. John Winchcombe II's political rise was particularly meteoric and probably equalled only by William Stumpe of Malmsbury. He was appointed JP in I540, acted as a commissioner for the subsidy of I 543-44 and benevolence of I 544-45, and was elected Member of Parliament in I545, I 547 and probably I553. ${ }^{127}$ In Reading, both first and second generation clothiers were active in borough government over long periods. Thomas Aldworth served as mayor of Reading four times, Thomas Kendrick and William Kendrick, once each. ${ }^{228}$ As mayor, Thomas Aldworth represented the borough in Parliament in I558 and I559. ${ }^{\text {I29 }}$ Thomas Dolman I provides an exception but this may be an accident of timing: working clothiers were increasingly excluded from county government and national politics from the I560s onwards and Newbury did not become formally self-governing until I $595 \cdot{ }^{\mathrm{I}}{ }^{\circ}$ Public service provided benefits as well as costs. As

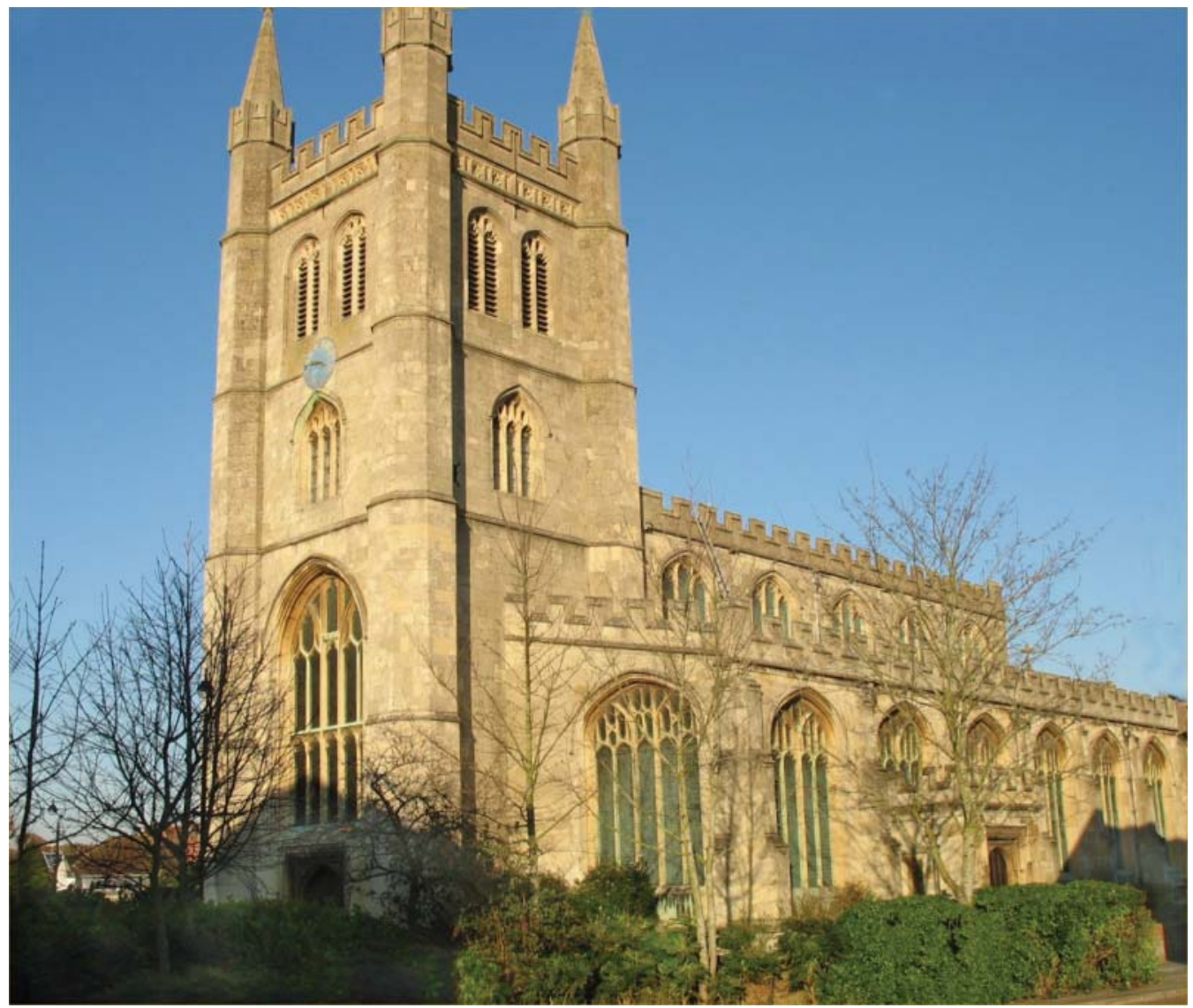

FIG. 3. St Nicholas's Church, Newbury, Berkshire, 2008. Photo: Roy Jackson. 


\section{Boom-Time Freaks or Heroic Industrial Pioneers?}

the sixteenth century progressed, the increasingly constrictive regulation of trade and industry by both royal government and local authorities necessitated action on the part of clothiers. John Winchcombe II, for example, played a leading part in the successful lobbying campaign to resist the statutory revision of standard kersey measurements, I $536-42 .{ }^{\text {I3I }}$

Whilst Deloney exaggerated John Winchcombe's paternalism and commitment to the commonweal for literary and political effect, the philanthropic impulse of leading Berkshire clothiers was undisputedly strong. Probate evidence reveals that they made generous testamentary donations across a wide range of charitable causes, including the church, education, municipal improvements and the relief of poverty. ${ }^{132}$ The driving force behind their entrepreneurial philanthropy was complex, encompassing religious, humanitarian and practical considerations as well as the desire to commemorate personal success and civic duty. John Winchcombe I made substantial contributions to the rebuilding of Newbury parish church, including a bequest of $£_{40}$ in his will (Fig. 3 ). ${ }^{133}$ Walter Bye left $£_{40}$ to the hospital in Reading. ${ }^{134}$ John Winchcombe II left $£_{50}$ for the relief of the poor with a further $£_{\mathrm{I}} 37 \mathrm{~s}$ Iod to be '... geven and deliuered to the pore people as I have named them by the streates, towns and mansions ...' ${ }^{\mathrm{I} 35}$ Thomas

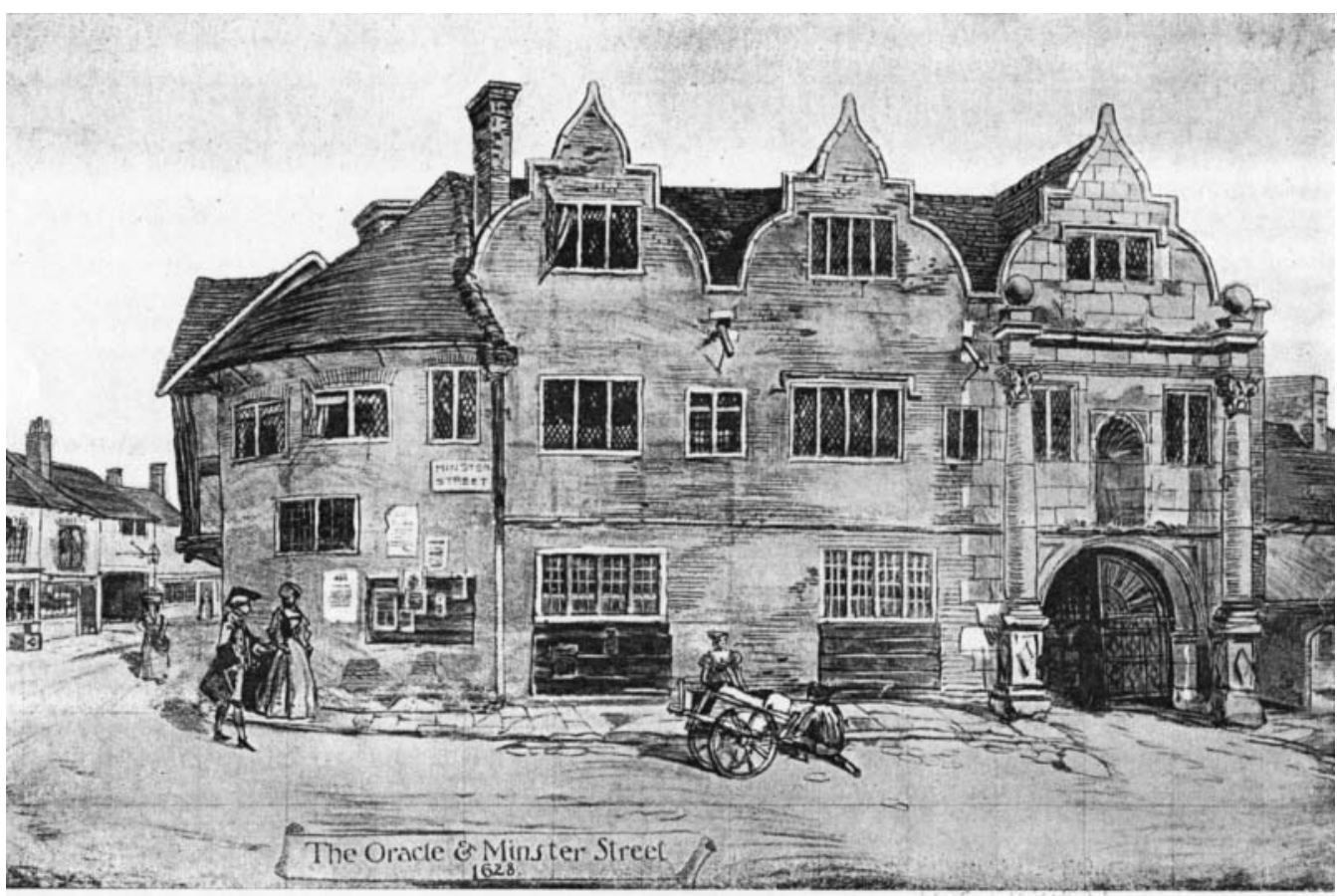

The Oracle and Minster Street, 1628, from a drawing.

FIG. 4. Undated drawing of the Reading Kendrick Workhouse, 'The Oracle in I628', Reading Library Local Studies Collection, R/KP ILL IoI7A.

By kind permission of Reading Library, Local Studies Collection. 
Dolman I's paternalist credentials are demonstrated not only by his testamentary dispositions but by the frequency with which he and his wife stood as godparents to the children of Newbury. ${ }^{\mathrm{I} 6}$ William Kendrick, perhaps inspired by the exceptional philanthropy of his brother, John, who bequeathed about $£_{\mathrm{I} 9,000}$ to charitable causes, including $£_{\mathrm{I} 3,200}$ to establish workhouses, tradesmen's loan funds, maids' dowries and morning prayer charities in Reading and Newbury, founded almshouses in Reading for former cloth-workers (Fig. 4). ${ }^{\mathrm{I} 37}$

\section{Conclusion}

The achievement of Berkshire clothiers stands out against the seeming reluctance to experiment with extensive centralization and conglomeration in other English clothing regions. William Stumpe of Malmesbury, Wiltshire (died I552) is the only English clothing entrepreneur known to have centralized production on a comparable scale, albeit the drive to centralize production in the I530s and I540s initially extended into other counties. ${ }^{138}$ The weavers of Lavenham, Ipswich, Hadleigh and Bergholt in Suffolk, for example, complained in a petition of I 539 that clothiers were employing weavers and fullers in their own houses and impoverishing independent craftsmen. ${ }^{\mathrm{I}}{ }^{39}$ Alan Dyer and Herbert Heaton acknowledge the possibility of early undocumented and short-lived centralization and conglomeration in Worcester and Yorkshire alongside the putting-out and small clothier systems. ${ }^{\text {I0 }}$ In the Kentish cloth industry, which competed directly with Berkshire in the production of high-quality, fully-manufactured broadcloths and kersies, probate evidence suggests that even though many clothiers dyed their own wool, they continued to employ independent weavers and shearmen. Michael Zell finds little evidence of clothiers investing in fulling mills and suggests that even in the late sixteenth and early seventeenth centuries a substantial number of Kentish broadcloths may have been dressed in London and that some were exported undressed. ${ }^{\text {III }}$ The pace of centralization and agglomeration was similarly slow in mainland Europe. The Spanish city of Segovia is the only cloth centre known to have experimented with the development of the proto-factory in the sixteenth century. Like Reading and Newbury, Segovia produced high-quality, fully-manufactured cloths, some of which were exported to America. The city's economy was similarly highly specialized, with nearly 60 per cent of the population employed as textile workers in the 1560 s and seven wealthy clothiers providing work to up to 300 employees with some roo employed in workshops on site. By I700, however, the industry was declining and the putting-out system re-established itself. ${ }^{\text {I42 }}$

For contemporaries, John Winchcombe II's entrepreneurial success and reputation rested upon his organizational innovation, creation of wealth, contribution to the gross national product and provision of employment to the poor. Late twentieth-century historians judge the Berkshire clothier harshly because they focus upon the short duration of his family business and limited impact of his organizational innovation. In reality few cloth-making businesses established by entrepreneurs in Reading and Newbury from the fifteenth to the seventeenth century, survived more than three generations. Most disappeared within the space of one or two generations. ${ }^{\mathrm{I} 3}$ Whilst social attitudes played an important part in shaping and determining the duration of entrepreneurship, their role must not be overplayed. Although successful clothiers strove to establish gentry 


\section{Boom-Time Freaks or Heroic Industrial Pioneers?}

dynasties or encouraged their offspring to pursue careers in trade, the law and church, family cloth-making businesses were frequently transferred intact and well funded to a younger son. Whilst almost all successful clothiers succumbed to the lure of conspicuous consumption, safe investment opportunities and public service, they did not necessarily cease to pursue occupational success or abandon their commitment to profit maximization. Indeed, the diversion of effort and resources often generated secondary benefits such as improved brand visibility or increased networking opportunities.

The critical factors were invariably the health and competence of successive clothmaking generations and the buoyancy of the cloth trade. Business succession strategies were easily thwarted by an untimely death. Both Henry Winchcombe and Walter Bye were forced to leave their businesses to minors. ${ }^{\text {I44 }}$ Third-generation clothiers such as Henry Winchcombe and Thomas Kendrick appear to have enjoyed less success, albeit in more difficult trading circumstances than their fathers and grandfathers. ${ }^{\mathrm{I} 5}$ The cloth export trade was extremely volatile and the profit margins of manufacture sensitive to external intervention. It cannot be coincidence that many cloth-making families, including the Winchcombes, Dolmans and Kendricks, retired from manufacture or downsized their business operations during prolonged slumps in demand or following government intervention to regulate manufacture. As successful entrepreneurs, they clearly recognized and seized the moment to withdraw or reduce their investment in cloth-making. Bankruptcy struck occasionally, but was not necessarily terminal, as the case of Brian Chamberlain in Newbury demonstrates. ${ }^{\mathrm{I} 46}$

Concern with the short duration of entrepreneurship is to some degree misplaced. The impact of business failure or disinvestment upon the early modern clothing region was limited, provided new entrepreneurs emerged to sustain or re-invigorate manufacture. The supply of entrepreneurial talent in Reading and Newbury was replenished until the trading conditions of the seventeenth century rendered the opportunity costs of urban cloth-making unacceptable to both existing and aspirant entrepreneurs and de-industrialization became unavoidable. ${ }^{\mathrm{I} 7}$ There was little incentive to invest in a declining cloth industry when alternative commercial, industrial, and agricultural investments abounded in the area due to the expansion of London and the capital's insatiable demand for food and drink. ${ }^{\mathrm{I} 48}$ The proto-factory system pioneered by Berkshire clothiers was not lost but preserved in folk memory and popular literature and ultimately adopted and adapted by their longtime northern competitors as they increased the number and quality of the cloths they produced in the later seventeenth century. When Defoe visited Halifax around I700, he found the houses of clothiers '... full of lusty fellows, some at the dye-vat, some dressing the cloths, some in the loom .... Nearby were' '... small dwellings, in which dwell the workmen which are employed, the women and children of whom, are always busy carding, spinning, etc .... 49 Over the following century, Yorkshire's leading clothing entrepreneurs developed some of the largest non-mechanized textile mills in the north prior to the industrial revolution. ${ }^{150}$

ACKNOWLEDGEMENTS

I should like to express my gratitude to my husband, Roy Jackson, who took photographs for this article, to West Berkshire Museum and Reading Library (Local Studies Collection) for permission to use images from their collections, to colleagues and to Textile History's readers who provided feedbacks on draft versions, and to Kellogg College and the Department for Continuing Education in the University of Oxford for their support. 


\section{REFERENCES}

${ }^{\mathrm{I}}$ John Skelton, The Complete English Poems ed. John Scattergood (Harmondsworth: Penguin, I983); Lucy Toulin Smith ed., The Itinerary of John Leland in or about the Years 1535-1543, Vol. I. Parts I-III (London: Centaur Press, I964); Francis O. Mann ed., The Works of Thomas Deloney (Oxford: Clarendon Press, I9I2); John Aubrey, Brief Lives: a Modern English Version, ed. Richard W. Barber (Woodbridge: Boydell Press, 1982); Thomas Fuller, The Worthies of England ed. John Freeman (London: George Allen \& Unwin, I952); Daniel Defoe, A Tour Through the Whole Island of Great Britain (Ist publ. I724-26, Harmondsworth: Penguin, I97I).

${ }^{2}$ British Library, I079.i.I4 (I3), The History of Jack of Newbury, called The Clothier of England; D.287(I), Jack of Newbury, written by James Hook and published in London $c$. 1750 .

${ }^{3}$ Donald C. Coleman, Industry in Tudor and Stuart England (London: Macmillan, 1975), pp. II-I2; Anthony R. Bridbury, Medieval English Clothmaking (Basingstoke: Heinemann, I982), pp. $26-27$.

${ }^{4}$ F. M. L. Thompson, Gentrification and the Enterprise Culture: Britain $1780-1980$ (Oxford: Oxford University Press, 200I), p. 5 .

5 The guild system was never well suited to the production of cloth because of the number and diversity of the manufacturing processes. The putting-out system facilitated expansion with minimal overheads because outworkers were employed on piece-rates in their own homes and often provided their own tools and equipment. Centralization was pursued through progressive investment in successive stages of manufacture (vertical integration) on one or more sites and in exceptional cases led to the development of proto-factories (large unmechanized workshops).

${ }^{6}$ See above, pp. I $55^{-56 .}$

7 Reading broadcloths were heavyweight woollen cloths, plain woven and dyed in the wool. By the late sixteenth century the cloths were often described as medley or mingled cloths because of the distinctive finish achieved by mingling coloured wools before carding and weaving. The royal charter granted to Reading weavers in 1520 specified that Reading cloths were to contain seven quarters and a half at least in breadth throughout the cloth, six and 20 yards in length when thickened at the water and two yards in breadth when dry and thickened. The I552 Act for True Making of Woollen Cloth specified that long broadcloths made in the town of Reading and the counties of Kent, Sussex and Yorkshire were to measure 28 to 30 yards in length and seven quarters in width between the lists at the water, whilst weighing at least $90 \mathrm{lbs}$ (reduced to $86 \mathrm{lbs}$ in 1557) when dry after fulling. The maximum length and minimum breadth of 'long broadcloths and cloths which shall be made of died wools and mingled colours' were further revised in I607. Kersey was a smaller and lighter woollen fabric. The 1552 statute specified that each ordinary kersey was to measure between I 7 and I8 yards in length at the water (revised to I6-I8 yards in I557) and to weigh at least 20 lbs when dry after fulling, whilst each sorting kersey was to measure between I7 and I8 yards in length at the water, but when dry after fulling was to weigh at least $23 \mathrm{lbs}$ (reduced to $22 \mathrm{lbs}$ in 1557 ). The specifications were revised in I606. Berkshire Record Office, R/HMC/I, no. I6, Reading Weavers' Charter of Privileges; Statutes of the Realm, 5 \& 6 Ed. VI, c.6; 4 Phil. \& Mary, c. 5, 4 Jas. I, c. 2, 27 Hen VIII, c. I2; 33 Hen VIII, c. I8, 5 \& 6 Ed. VI, c. 6; 4 Phil. \& Mary, c. 5, 3 Jas. I, c. I6.

${ }^{8}$ William G. Hoskins, Social and Economic History of England, 5 , The Age of Plunder: the England of Henry VIII, I500-47 (Bath: Longman, 1976), pp. 94-95; Alan D. Dyer, The City of Worcester in the Sixteenth Century (Leicester: Leicester University Press, I973), p. 8I.

9 Christine A. Jackson, 'The Berkshire Woollen Industry I 500-I650' (unpublished PhD thesis, I993, Reading University), pp. I9-22, I55. Reading Abbey was dissolved in September I539.

${ }^{10}$ Ibid., pp. 20-23.

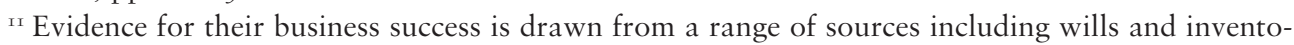
ries, merchants' account books, commercial correspondence, borough records, state papers, Privy Council records and tax records. 


\section{Boom-Time Freaks or Heroic Industrial Pioneers?}

${ }^{12}$ Deloney uses material, for example, from Boccaccio's Decameron. Warren E. Roberts, 'Folklore in the Novels of Thomas Deloney', in Winthrop E. Richmond ed., Studies in Folklore (Bloomington: Indiana University Press, I957), p. I23. His interest in cloth-making may derive from his own early training and employment as a silk weaver.

${ }^{{ }^{13}}$ Fuller, for example, writing mid-seventeenth century, clearly identifies his subject as John Winchcombe I and describes him as 'the most considerable clothier (without fancy and fiction) England ever beheld'. Fuller, Worthies, p. 88. Defoe, writing half a century later, refers rather cautiously to 'the famous Jack of Newbery' whose story is 'almost grown fabulous' and mistakenly places the clothier in James I's reign. Defoe, Tour, p. 268. Both John Winchcombes use the alias Smallwood, as do members of the succeeding generation.

${ }^{14}$ The National Archives, prob/II/19 q. 27.

is The National Archives, E315/464, Military Survey of Berkshire, I522.

${ }^{16}$ The National Archives, EI79/73/I32, EI79/73/I24, Lay Subsidy, I524-25. Winchcombe's assessment for the Anticipation of 1523 was based on moveable goods and amounted to $£_{23}$. He contributed $£_{2} 8$ to the subsidy of I 525 , representing 23 per cent of Newbury's tax bill of $£_{\text {I } 20} 3 s$ IId. See also Margaret Yates, Town and Countryside in Western Berkshire, C.I327-I600 (Woodbridge: Boydell and Brewer, 2007), p. II2.

${ }^{17}$ Alec Betterton and David Dymond, Lavenham: industrial town (Lavenham: Terence Dalton Limited, I989), p. 42. Eileen Power, The Paycockes of Coggleshall (London: Methuen, I920), p. 49. Hoskins, The Age of Plunder, p. 39. William G. Hoskins, Provincial England: Essays in Social and Economic History (London: MacMillan, 1963), p. 73. Although Spring's wealth was exceptional, Thomas Smyth of Long Melford was valued at $£ 600$ on moveables and several other clothiers in the Babergh Hundred of Suffolk at $c$. $£_{4} 00$. John Pound ed., The Military Survey of I 522 for Babergh Hundred (Woodbridge, Boydell and Brewer, I986), pp. 75, 83 .

${ }^{18}$ Florence Edler, 'Winchcombe Kersies in Antwerp', Economic History Review, Ist ser., VII (1936), pp. $57-58$.

is Stanley T. Bindoff ed., The History of Parliament: the House of Commons, I 509-58, III (London: HMSO, I982), p. 632.

${ }^{20}$ Edler, 'Winchcombe kersies', p. 59.

${ }^{21}$ Easter fell on 6 April I539. The National Archives, SP/I/I43, Letter from Winchcombe to Cromwell.

${ }^{22}$ Edler, 'Winchcombe Kersies', p. 60.

${ }^{23}$ Mercers' Company Archives, London, Sir Thomas Gresham's Daybook, I546-52.

${ }^{24}$ Mann, Works of Thomas Deloney, pp. 20-2I. Deloney appears to contradict himself in the title-page to his novel when he claims that Winchcombe 'set continually five hundred poore people at worke, to the great benefite of the Common-wealth'. But this may refer merely to the number of unskilled workers employed.

${ }^{25}$ Bindoff, Commons, III, p. 405; Peter H. Ditchfield ed., Victoria County History of Berkshire, IV (London: St Catherine's Press, I924), p. IIo.

${ }^{26}$ Barbara McClenaghan, The Springs of Lavenham (Ipswich: W. E. Harrison, I924), p. 7.

${ }^{27}$ Mercers' Company Accounts, London, Gresham's Daybook, entry no. 5250; Southampton Record Office, Southampton Brokage Books, SC5//45. See David Peacock, 'Dyeing Winchcombe Kersies and Other Kersey Cloth in Sixteenth-Century Newbury', Textile History, xxxvII, no. 2 (2006), pp. 190-92; and Yates, Town and Countryside, p. 84.

${ }^{28}$ The National Archives, prob/2/345. In his will of the previous year, Winchcombe valued the lease of his dyehouse 'with the howse and furniture p[er]teyning thereunto' at $£ 60$. The National Archives, prob/II/40 q. 26.

${ }^{29}$ David Peacock, 'The Winchcombe Family and the Woollen Industry in Sixteenth-Century Newbury' (unpublished PhD thesis, 2003, Reading University), pp. 55-57.

30 The National Archives, prob/ri/I9 q. 27. 
${ }^{31}$ Oxford Archaeology '24 Northbrook Street, Newbury'; Berkshire Record Office, Wills, D/ $\mathrm{AI} / \mathrm{I} 32 / \mathrm{I} 83$.

${ }^{32}$ The National Archives, LR/2/187, fols. II2-23, Survey of the Manor of Newbury.

${ }_{33}$ James Gairdner and Robert H. Brodie eds, Letters and Papers Foreign and Domestic of Henry VIII, XV, no. 44, p. I09; no. 88, p. II3.

${ }^{34}$ Ibid., XVII, II 54 no. 30, p. 634; SGCA, leases, xv. 5.4.

${ }^{35}$ Bindoff, Commons, III, p. 633. The inquisition post mortem value of Spring's lands in 1523 was $£_{370} £_{3} 80$ according to separate figures provided in the Chancery and Exchequer series. Hoskins, Age of Plunder, p. 39.

${ }^{36}$ The National Archives, prob/2/345.

${ }^{37}$ Kenneth H. Rogers, Warp and Weft: the Somerset and Wiltshire Woollen Industry (Buckingham: Barracuda, I986), p. 24.

${ }^{38}$ Mercers' Company Archives, London, Gresham's Day Book.

${ }_{39}$ Berkshire Record Office, T/R255, p. 3I, Transcript of Newbury Parish Register, Burials I 538-64; Jackson, 'Berkshire Woollen Industry', p. I47.

${ }^{40} \mathrm{~A}$ tod was a measurement of quantity used for weighing wool in and was normally 28 pounds.

${ }^{4 \mathrm{I}}$ Berkshire Record Office, D/Ar/I32/I83, Wills.

${ }^{42}$ Warp and Weft, p. 24.

${ }^{43}$ Coleman, Industry in Tudor and Stuart England, pp. II-I2; Bridbury, Medieval English Clothmaking, pp. 26-27.

${ }^{44}$ Mercers' Company Accounts, London, Gresham's Day Book.

${ }^{45}$ The National Archives, prob/1r/57 q.47. His will was modified in I 575 .

${ }^{46}$ The National Archives, Er79/73/43, Lay Subsidy I 543-45.

${ }^{47}$ Michael MacLeod, Shaw House unmasked (Skye, I999), p. 4.

${ }^{4}$ Ibid., pp. 9, I7.

${ }^{49}$ The conglomeration of six or more looms would have been considered substantial.

${ }^{5 \circ}$ Mercers' Company Archives, London, Gresham's Daybook. Gresham purchased I,322 kersies from Bennet, August I548-May I550.

${ }^{51}$ The National Archives, Eror 347/I7, Exchequer Accounts, Aulnage, List of Clothiers; George D. Ramsay ed., John Isham Mercer and Merchant Adventurer, two account books of a London merchant in the reign of Elizabeth I, xxI (Gateshead: Northants. Rec. Soc., I962), p. lv.

${ }^{52}$ St George's Chapel Archives, Windsor, xv. 54.9I; xv. 30.38, xv. 29.2, xv. 29.4, leases; xv. 58.I5, suits-at-law; The National Archives, C2/Eliz/C6/49, Chancery, Six Clerks Office, Pleadings I $558-1603$.

53 The National Archives, prob/ri $/ 80$, q. 87.

${ }_{54}$ The National Archives, prob/ıI/136, q. I08; Money, Newbury, p. 549.

${ }_{55}$ Berkshire Record Office, D/AI/54/74ab, wills.

${ }^{56}$ Berkshire Record Office, R/HMC/I, no. I6, Reading Weavers' Charter; Jackson, 'Berkshire Woollen Industry', pp. I04-05.

57 The National Archives, prob/Ir/59 q. 6; Berkshire Record Office, R/HMC/LVI, Reading Gild Rules.

${ }^{58}$ The National Archives, prob/II/84 q. 58; prob/II/67 q. 29; prob/II/62 q. 27.

${ }^{59} \mathrm{~A}$ stockard was a card fixed to a stock or other support which was used to prepare wool for spinning.

${ }^{60}$ The National Archives, prob/2/4II; prob/II/62 q. I8.

${ }^{61}$ Thomas Bye, fuller, served as Mayor of the Merchant Gild of Reading, I516-I7. Walter Bye served as burgess and was related by marriage to the Watlingtons and Kendricks. John M. Guilding ed., Records of the Borough of Reading: Diary of the Corporation, I (London: James Parker \& Co., I892-96), p. I03.

${ }^{62}$ Drapers' Company Archives, London, Freedom List, I567-I656, FAI. 


\section{Boom-Time Freaks or Heroic Industrial Pioneers?}

${ }_{63}$ Guilding, Reading Records, I, p. 448.

${ }^{64}$ The National Archives, prob/II/73 q. 9; Oxford Archaeology, 'Reading Oracle', I, pp. 22-36; Berkshire Record Office, D/QR/I9/2/I, fols I-2, IO-II, John Kendrick Accounts, Charity, I625-50. In I568, Thomas Kendrick received dispensation from the Privy Council to exercise '.. the mistery of making woollen cloths long or short and kerseys, pynned whites and plaine streites and to sell the same .... He acquired a substantial house and cloth-making premises in Minster Street and invested in land in Reading, Sindlesham, and Shinfield before his early death c. I588. Calendar of Patent Rolls, iv, no. II32, p. I97; The National Archives, prob/II/73 q. 9.

${ }^{65}$ Berkshire Record Office, Reading Box 67, Bundle 3, item 2, Charity Papers.

${ }^{66}$ Guilding, Reading Records, II, pp. 433-35; Berkshire Record Office, D/A2 c. 6I, p. 77, Berkshire Archdeaconry Court Records, Deposition Book, I616-20.

${ }^{67}$ Christine Jackson ed., Newbury Kendrick Workhouse Records I627-4I, VIII (Reading: Berkshire Records Society, 2004), p. 2II.

${ }^{68}$ The National Archives, prob/II/73 q. 9.

${ }^{69}$ British Library, Add. MS 7242I, Privy Council Enquiry into the Kendrick Legacy.

${ }^{70}$ M. Appleby, The Kendrick Book (Reading: Bradley, I948), pp. 55-56.

${ }^{71}$ Guilding, Reading Records, IV, p. 296.

${ }_{72}$ Drapers' Company Archives, FAI, Freedom List, I567-I656; QBIQuarterage Book, I605-I8.

${ }^{73}$ Leo Noordegraaf, 'The New Draperies in the northern Netherlands, I500-I899', in Negley B. Harte ed., The New Draperies in the Low Countries and England (New York: Pasold Research Fund, Oxford University Press, I997), p. I78.

${ }^{74}$ Christopher G. A. Clay, Economic Expansion and Social Change: England 1500-I700, II (Cambridge: Cambridge University Press, 1984), pp. I09-10.

${ }^{75}$ Peter H. Ramsey, 'Two Early Tudor Cloth Merchants: Sir Thomas Kitson and Sir Thomas Gresham', in Marco Spallanzani ed., Produzione, commercio e consumo dei panni di lana (nei secoli XII-XVIII) (Florence: L. S. Olschki, I976), pp. 388-89.

${ }^{76}$ Jackson, 'Woollen Industry', pp. I49-50.

${ }_{77}$ Ibid., pp. 233-49; Astrid Friis, Alderman Cockayne's Project and the Cloth Trade (London: H. Milford, Oxford University Press, 1927), pp. I29-30, 62-65.

${ }^{78}$ Peter J. Bowden, The Wool Trade in Tudor and Stuart England (London: MacMillan, I97I), pp. 62-63.

${ }^{79}$ Jackson, Workhouse Records, VIII, passim; Peacock, 'Dyeing Winchcombe Kersies', pp. I87-202.

${ }^{80}$ Both Reading and Newbury boasted several fulling mills within their boundaries and there were numerous other mills within easy reach of the two towns. Christine Jackson, 'The Berkshire Woollen Industry c.1500-1650', in Joan Dils ed., An Historical Atlas of Berkshire (Reading: Berkshire Record Society, I998), pp. 52-53.

${ }^{81}$ About 38.5 per cent of land in the region was enclosed compared with 23.9 per cent for the county as a whole. Ross Wordie ed., Enclosure in Berkshire, I485-I885, V (Reading: Berkshire Record Society, 2000), pp. xxvi-xlxvii.

${ }^{82}$ Calculated from the lay subsidy of $1523-27$. Alan D. Dyer, 'Ranking Lists of English Medieval Towns', in D. Palliser ed., The Cambridge Urban History of Britain, I, 600-I540 (Cambridge: Cambridge University Press, 2000), pp. 76I-67.

${ }^{83}$ Calculated using decadal count of baptisms. Jackson, 'Berkshire Woollen Industry', pp. 35-36, I90-9I.

${ }^{84}$ John Styles, 'Embezzlements, Industry and the Law in England, I500-I800', in Maxine Berg, Pat Hudson and Michael Sonenscher eds, Manufacture in Town and Country Before the Factory (Cambridge: Cambridge University Press, 1983), pp. 175-78.

${ }^{85}$ Berg et al., Manufacture in Town and Country, pp. 6-8, 29.

${ }^{86}$ Ibid., p. 5 . 
${ }^{87}$ Calendar of Patent Rolls, iv, no. II32, p. 197.

${ }^{88}$ Mann, Works of Thomas Deloney, p. 3.

${ }^{89}$ Berkshire Record office, D/AI/I/I75/27, Wills; The National Archives, prob/II/80 q. 80.

${ }^{\circ}$ Michael L. Zell, 'Credit in the Pre-Industrial English Woollen Industry', Economic History Review, 49, no. 4 (I996), p. 669.

${ }^{91}$ Jackson, Workhouse Records, pp. 208-Ir.

${ }_{92}^{2}$ Mercers' Company Archives, Gresham Daybook, Entries 4946, 495I, 4954.

${ }_{93}^{3}$ Mark Casson, The Enterpreneur: An Economic Theory (Oxford: Blackwell, 2nd edn 2003), pp. $28-30$.

${ }^{94}$ The National Archive, prob/II/I9 q. 27; prob/II/57 q. 47.

${ }_{95}$ See above, pp. I5I-52.

${ }_{96}$ The National Archives, prob/11/59 q. 6; prob/11/73 q. 9.

${ }_{97} \mathrm{Ibid}$., prob/II/40 q. 26; McLeod, Shaw House, p. 6.

${ }^{98}$ Joan Dils, Redding, I540-I640 (Reading, I98I), p. 2I.

${ }_{99}$ The National Archives, LR/2/I87, fols II $2-32$, 3I4-44, Survey of the Town of Reading. See also above, p. I53.

${ }^{100}$ Berkshire Record Office, D/Ar/I32/I83, Wills; Oxford Archaeology, '24 Northbrook Street, Newbury'; Reading Library, John Willis's Plan of the Town of Newbury and Speenhamland, I768, LM 756.

Ior Bodleian Library, DOUCE, D225(I), Sketch by John Flaxman in Deloney 'Jack of Newbury'.

${ }^{102}$ Walter Money, 'Archaeological Notes', Transactions of the Newbury District Field Club, v (I895-I9II), p. 2I2.

${ }_{103}$ The National Archives, prob/ris/40 q. 26.

${ }^{104}$ Berkshire Record Office, D/Aı/35/r 88b, Wills.

${ }^{\text {ros }}$ Laurence Stone and Jeanne C. Fawtier Stone, An Open Elite? England, 1540-1880 (Oxford: Clarendon Press, 1984), p. 70; TNA, prob/11/40 q. 26.

${ }^{106}$ The National Archives, prob/II/73 q. 9.

ro7 The National Archives, prob/II/57 q. 47; McLeod, Shaw House, p. I 5.

${ }^{108}$ The National Archives, prob/ri $/ 59$ q. 6.

rog Stone and Stone, An Open Elite, pp. 3-4.

Iro Michael Mascuch, 'Social Mobility and Middling Self-Identity: the Ethos of British Autobiographers, I600-I750', Social History, Xx, no. I (I995), pp. 45-6I.

IIr Thomas More, Utopia, trans. Paul Turner (London, I965); Aquinas, Selected Political Writings, ed. Alexander P. D’Entreves, trans. J. G. Dawson (Oxford: Basil Blackwell, I970); James R. Farr, Artisans in Europe, I300-I9I4 (Cambridge: Cambridge University Press, 2000), pp. IO-I5.

${ }^{I 12}$ Although Protestant writers and preachers promoted the value and dignity of labour, and Puritans such as William Perkins advised that wealth was a sign of God's blessing and could be enjoyed in good conscience provided it was deployed wisely, their preaching merely brought greater appreciation for industrial and commercial success and had a negligible impact upon the social status of clothiers. Laura C. Stevenson, Praise and Paradox: Merchants and Craftsmen in Elizabethan Popular Literature (Cambridge: Cambridge University Press, 1984), p. I34.

${ }^{113}$ Martin Weiner, English Culture and the Decline of the Industrial Spirit, 1850-1980 (Cambridge: Cambridge University Press, I98I), p. 97.

${ }^{\mathrm{II}} 4$ George D. Ramsay, The Wiltshire Woollen Industry in the Sixteenth and Seventeenth Centuries (London: H. Milford, Oxford University Press, I943), pp. 46-47.

${ }^{115}$ Walter Money, The History of Newbury (Newbury: W. J. Blacket, 1905), pp. 206-07.

${ }^{116}$ Letters and Papers Foreign and Domestic of Henry VIII, Xv, no. I4, p. 6.

${ }^{117}$ Bindoff, Commons, III, p. 633.

${ }^{\mathrm{Ir} 8}$ Catalogue for Exhibition of the Royal House of Tudor, London, I890, no. $20 \mathrm{I}$.

II Bindoff, Commons, III, p. 633. 


\section{Boom-Time Freaks or Heroic Industrial Pioneers?}

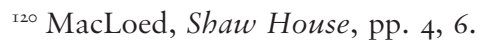

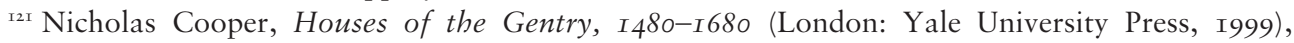
pp. $79-80$.

${ }^{122}$ W. Harry Rylands ed., The Four Visitations of Berkshire (London: The Harleian Society, I907), p. 60; MacLeod, Shaw House.

${ }^{123}$ Joseph Foster ed., Alumni Oxonienses, vol. I, Early Series (Oxford: Parker \& Co., I89I), p. $4 \mathrm{I} 3$.

${ }^{124}$ Cooper, Houses of the Gentry, pp. 79-82, 268.

${ }^{125}$ Victoria County History, Berkshire, III, p. 219.

${ }^{126}$ Jonathan Barry, 'Bourgeois Collectivism? Urban Association and the Middling Sort', in Jonathan Barry and Christopher Brooks eds, The Middling Sort of People: Culture, Society and Politics in England, I550-I800 (Basingstoke: Palgrave MacMillan, I994), p. 87.

${ }^{127}$ Winchcombe may have sat in earlier Parliaments but the records are missing. Bindoff, Commons, III, p. 633.

${ }^{128}$ Guilding, Reading Records, I, pp. 220, 253-54, 563, 309.

${ }^{129} \mathrm{P}$. W. Hasler, The History of Parliament, the House of Commons, 1558-1603, II (London: HMSO, I98I), p. 333 .

${ }^{\text {I30 }}$ Money, Newbury, p. 5 II.

${ }^{\mathrm{I} 3 \mathrm{I}}$ Letters and Papers Foreign and Domestic of Henry VIII, xiv, Part I, no. 396, p. I57; xVI, no. 625 , p. 297.

${ }_{132}$ The National Archives, prob/II/I9 q. 27.

${ }^{\mathrm{I} 33} \mathrm{Ibid}$., prob/II/I9 q. 27.

${ }^{134} \mathrm{Ibid}$., prob/II/62 q. I8.

${ }^{\mathrm{I} 35} \mathrm{Ibid}$., prob/II/40 q. 26.

${ }^{136}$ BRO, T/R269, Transcript of Newbury Parish Register, Baptisms I 538-I634.

${ }^{137}$ The National Archives, prob/I I/I44; prob/II/I67.

${ }^{\mathrm{r} 38}$ Whilst Stumpe's industrial pragmatism in developing a redundant abbey site and investing in former monastic mills is impressive, his organizational innovation was less exceptional than that of his Berkshire contemporaries because he produced semi-manufactured cloths and thus operated a less complex manufacturing cycle. Bindoff, Commons, III, p. 405.

${ }^{139}$ Betterton and Dymond, Lavenham, p. 30.

${ }^{140}$ Herbert Heaton, The Yorkshire Woollen and Worsted Industries from the Earliest Times to the Industrial Revolution (Oxford: Clarendon Press, 2nd edn 1965), p. 92; Alan D. Dyer, The City of Worcester in the Sixteenth Century (Leicester: Leicester University Press, 1973), pp. 94-98.

${ }^{14 \mathrm{I}}$ Michael Zell, Industry in the Countryside: Wealden Society in the Sixteenth Century (Cambridge: CUP, I994), pp. I64-86.

${ }^{142}$ Robert S. Duplessis, Transitions to Capitalism in Early Modern Europe (Cambridge: Cambridge University Press, I997), p. I30; Angel García Sanz, Desarrollo y crisis del antiguo regimen en Castilla la Vieja: economiá y sociedad en tierras de Segovia I500-I8I4 (Madrid: Akal, I977), pp. 2I3-20.

${ }^{{ }^{143}}$ Of the 27 clothiers listed in Reading's guild lists $c$. I 570 only four (Walter Bye, Thomas Kendrick, Thomas Turner and Richard Watlington) boasted descendants in business in I623. Only the Byes were active in cloth-making in Reading for more than a century.

${ }^{\mathrm{I} 44}$ Berkshire Record Office, Wills, B222d; The National Archives, prob/II/62 q. I8.

${ }^{145}$ See above, pp. I5I-52, I54-55.

${ }^{146}$ See above, p. I52.

${ }^{147}$ Jackson, 'Berkshire Cloth Industry', pp. 233-49.

${ }^{148}$ Hoskins, Plunder, p. I57; Frederick J. Fisher, 'The Development of the London Food Market, I540-I640', Economic History Review, x (I939-40), p. 5I; James A. Galloway ed., 'One Market or Many? London and the Grain Trade of England', in J. A. Galloway ed., Trade, Urban Hinterlands and Market Integration C. I300-I600 (London: Centre for Metropolitan History, Institute of Historical 


\section{Christine JaCKSON}

Research, 2000), pp. 28-29. For example in I60I the former clothier, Richard Watlington, left his dwelling house to his daughter Elizabeth and her husband William Iremonger, together with 'my brewehouse, my scalles, my woodbarton, all my brewing vesseles, furnaces and moveables in my brewhouse and whatsoever to my brewehouse belongith, w[i]th the horse and carte used about the same .... The National Archives, prob. II/98 q. 60.

${ }^{149}$ Defoe, Tour, pp. 493-94, 500.

${ }^{150}$ William B. Crump, The Leeds Woollen Industry $1780-1820$ (Leeds: Thoresby Society, I93I), pp. 24-25, 3I.

Christine Jackson is lecturer in history in the Department for Continuing Education and fellow of Kellogg College at the University of Oxford. Her research interests lie in early modern urban history and particularly the Berkshire towns of Reading, Newbury and Abingdon. Her publications focus on urban politics, woollen manufacture and the relief of poverty. 